\title{
A review of the powderpost beetle genus, Xylopertha Guérin-Méneville, 1845, with a new species and new synonymy (Coleoptera: Bostrichidae: Bostrichinae: Xyloperthini)
}

\author{
Lan-Yu LIU ${ }^{1, *} \&$ Roger A. BEAVER ${ }^{2}$ \\ ${ }^{1}$ Department of Science Communication, National Pingtung University, No.4-18, Minsheng Rd, \\ Pingtung City, Pingtung County 90049, Taiwan. \\ ${ }^{2} 161 / 2$ Mu 5, Soi Wat Pranon, T. Donkaew, A. Maerim, Chiangmai 50180, Thailand. \\ ${ }^{*}$ Corresponding author: liulysky@gmail.com \\ 2Email: rogerbeaver6@gmail.com \\ ${ }^{1}$ urn:1sid:zoobank.org:author:8A4ECE7C-2607-440D-B1BC-6E3B05EF02BB \\ ${ }^{2}$ urn:1sid:zoobank.org:author:EEF5C471-ECFB-4786-8E2F-13C5B5EC4F0D
}

\begin{abstract}
We review the three species currently placed in the genus Xylopertha Guérin-Méneville, 1845 , and describe a new species, Xylopertha elegans sp. nov., from Turkey. We propose the following new synonymy: Xylopertha Guérin-Méneville, 1845 (= Paraxylogenes Damoiseau, 1968); Xylopertha reflexicauda (Lesne, 1937) (= Paraxylogenes pistaciae Damoiseau, 1968). We give details of the sexual dimorphism, and summarise information on the distribution and biology of all species. A key to the species of Xylopertha is provided.
\end{abstract}

Keywords. Biogeography, key, new species, new synonymy, Paraxylogenes.

Liu L.-Y. \& Beaver R.A. 2017. A review of the powderpost beetle genus, Xylopertha Guérin-Méneville, 1845, with a new species and new synonymy (Coleoptera: Bostrichidae: Bostrichinae: Xyloperthini). European Journal of Taxonomy 380: 1-22. https://doi.org/10.5852/ejt.2017.380

\section{Introduction}

The tribe Xyloperthini Lesne, 1921 is the most species-rich in the Bostrichidae Latreille, 1802, and currently includes 34 genera (Borowski \& Węgrzynowicz 2007; Park et al. 2015; Liu et al. 2016a). The tribe has a worldwide distribution, but the individual genera are mostly confined to a single zoogeographical region or subregion (Borowski \& Węgrzynowicz 2007).

The genus Xylopertha Guérin-Méneville, 1845 was erected in a key to bostrichid genera, for several species previously included in the genus Apate Fabricius, 1775. In a footnote, Guérin-Méneville (1845) listed the 'types' of the genus as "Apate minuta Fabricius, truncata Dejean, longicornis Fabricius, sinuata Fabricius, etc.". Apate sinuata Fabricius, 1792 was selected as type species of the genus by Gorham (1883). Of the remaining species, truncata is a nomen nudum, minuta is now placed in Dinoderus Stephens, 1830, and longicornis in Tetrapriocera Horn, 1878 (Fisher 1950). Lesne (1901) erected a new genus, Xylonites Lesne, 1901, for two species, X. retusus (Olivier, 1790), originally described in the genus 
Bostrichus Geoffroy, 1762 (Olivier 1790), and X. praeustus (Germar, 1817), originally described in the genus Apate Fabricius, 1775 (Germar 1817). However, Schilsky (1899) synonymised Apate sinuata, the type species of Xylopertha, with Xylonites retusus. Fisher (1950) synonymised Xylonites Lesne, 1901 with Xylopertha Guérin-Méneville, 1854. The species included by Lesne (1901) in the genus Xylopertha sensu Lesne 1901, were transferred to a new genus, Xyloperthella Fisher, 1950 (Fisher 1950). Two more species have been added to Xylopertha since the publication of the monograph of Lesne (1901), X. reflexicauda (Lesne, 1937), and X. dunensis (Rai \& Chatterjee, 1964). Xylopertha dunensis has been synonymised with X. praeusta (Germar, 1817) by Borowski \& Singh (2017). Thus, Xylopertha currently includes three species (Borowski \& Węgrzynowicz 2007; Borowski \& Singh 2017).

In this paper we review the three species currently included in Xylopertha, and describe one further species, X. elegans sp. nov. We synonymise Paraxylogenes Damoiseau, 1968 with Xylopertha, and Paraxylogenes pistaciae Damoiseau, 1968 with $X$. reflexicauda. We also provide a key to the four species now included in Xylopertha.

\section{Material and methods}

In the course of this study, the senior author has examined all available types, and other specimens of Xyloperthini in the Paris Museum, other European museums, and certain private collections. We have examined type materials or reliably identified specimens of 31 out of 34 genera included in the tribe, and have checked the descriptions of the remaining three genera.

The following abbreviations are used for Museums and other collections:

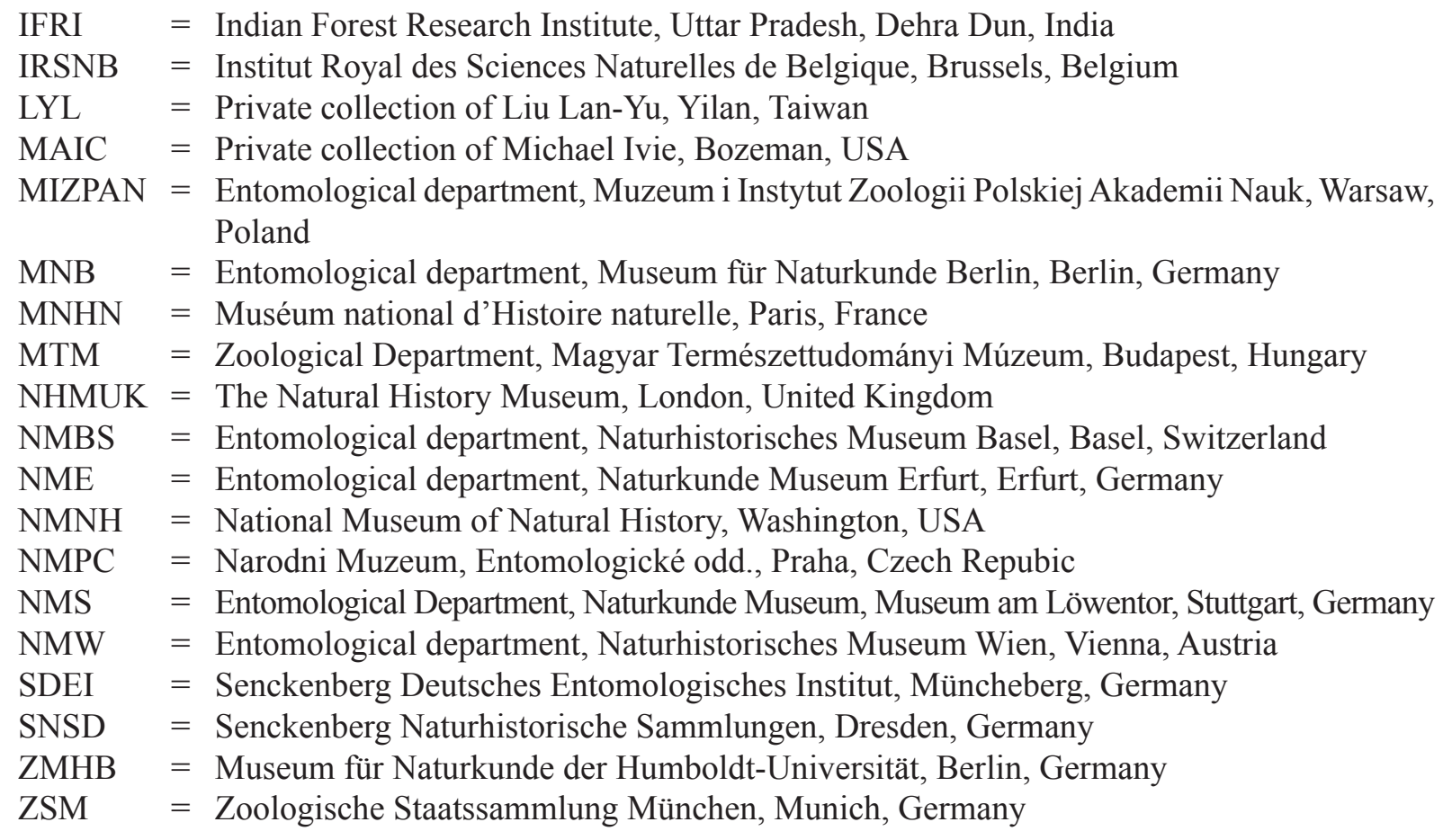

Photographs were taken with a Panasonic Lumix GX8 digital camera, combined using the program CombineZP, and optimized with Adobe Photoshop CS2.

The descriptions of the species are mainly based on Lesne (1901, 1937), with additional characters obtained from the examination of specimens from the museums and collections listed above, and dissection of specimens in LYL.

Actual quotations from data labels are enclosed in square brackets. 


\section{Results}

\section{Taxonomic account}

Superfamily Bostrichidae Latreille, 1802

Family Bostrichidae Latreille, 1802

Subfamily Bostrichinae Latreille, 1802

Tribe Xyloperthini Lesne, 1921

Genus Xylopertha Guérin-Méneville, 1845

Figs 1-4

Xylopertha Guérin-Méneville, 1845: XVII.

Xylonites Lesne, 1901: 575. Synonymy: Fisher 1950: 143.

Paraxylogenes Damoiseau, 1968: 1, syn. nov.

\section{Type species}

Type species of Xylopertha: Apate sinuata Fabricius, 1792 (Fabricius 1792:362). Subsequent designation by Gorham (1883: 215).

Type species of Xylonites: Bostrichus retusus Olivier, 1790 (Olivier 1790: 110). Subsequent designation by Fisher (1950: 143). Synonymy of Apate sinuata with Xylopertha retusa: Schilsky (1899: 291).

Type species of Paraxylogenes: Paraxylogenes pistaciae Damoiseau, 1968 (Damoiseau 1968: 4). Original designation.

\section{Diagnosis}

Xylopertha is the type genus of Xyloperthini Lesne (1921). The tribe is characterised by the lamelliform intercoxal process of the first abdominal ventrite, and the mandibles crossed at the tips (Lesne 1921; Fisher 1950; Liu \& Schönitzer 2011). The genus is distinguished from all other genera of Xyloperthini by the following combination of characters: frons with upwardly directed hairs (Fig. 2); antenna with nine antennomeres, the funicle with four and the club with three antennomeres, antennomeres of club lacking stiff, erect hairs, with indistinct sensory impressions near the apex of antennomeres 7 and 8, but absent on the last antennomere; pronotum without a lateral carina; elytral suture raised on declivity, but not strongly swollen; last ventrite of male with pleural pieces at sides; last ventrite of female emarginate.

Compared with the other five genera of Xyloperthini with nine antennomeres which occur in the same geographical area as Xylopertha, Scobicia Lesne, 1901 can be distinguished by the strong swelling of the suture on the elytral declivity in both sexes, and the last ventrite of the female is entire not emarginate; Psicula Lesne, 1941 is distinguished by the presence of an uncus on the anterior angles of the pronotum in both sexes, and the absence of pleural pieces in the male; Enneadesmus Mulsant, 1851 and Xylogenes Lesne, 1901 have distinctly delimited sensory areas on the first two segments of the antennal club, and the females of Enneadesmus have the last ventrite entire. The synonymy of Paraxylogenes with Xylopertha is discussed later in the paper.

\section{Description}

Body. Elongate, cylindrical, 4-8 mm long.

HEAD. Deeply inserted in prothorax, not visible from above. Frons simple, finely punctured, with fine, upwardly directed hairs, denser and much longer in female, fronto-clypeal suture distinct at sides, 

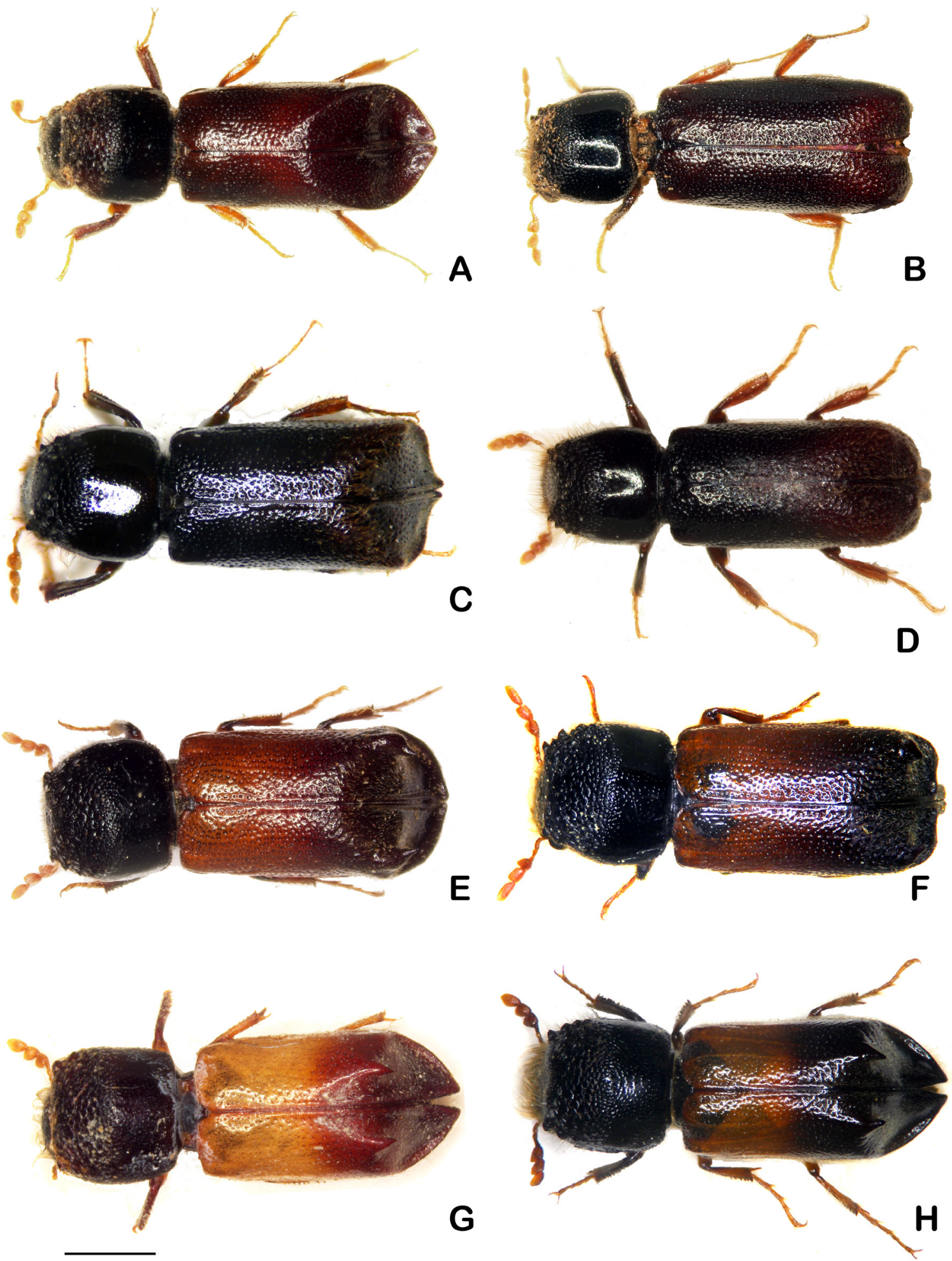

Fig. 1. Dorsal view of species of Xylopertha Guérin-Méneville, 1845. A. Xylopertha elegans

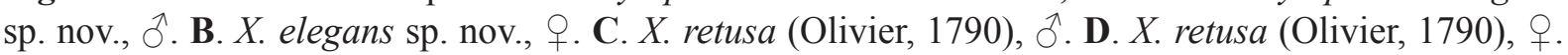

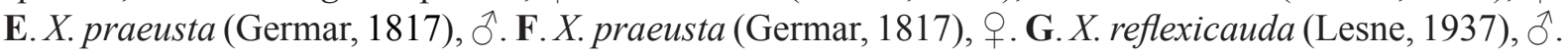
H. $X$. reflexicauda (Lesne, 1937),, . Scale bar $=1 \mathrm{~mm}$. 
strongly impressed in middle; clypeus transverse, finely and densely punctured; labrum transverse with a fringe of long hairs along anterior margin. Mandibles subequal, sharply pointed. Eyes small, oval, strongly projecting. Antenna with 9 antennomeres, first antennomere elongate, about twice as long as oval second, antennomeres 3-6 forming a loose funicle, each antennomere transverse, the fifth widest, together about as long as first antennomere of club, antennomeres 7-9 forming the elongate, compressed club, each antennomere of club with a dense covering of short, recumbent hairs, lacking distinct, clearly defined sensory impressions on all segments, antennomeres 7 and 8 subquadrate, subequal in length, last antennomere more elongate, oval.

Pronotum. Slightly wider than long, anterior angles with a small upcurved tooth without an uncus inserted a little behind margin, anterior margin between teeth slightly concave, not depressed behind the margin; area above anterior margin flat or weakly impressed, strongly, densely punctured, without teeth;
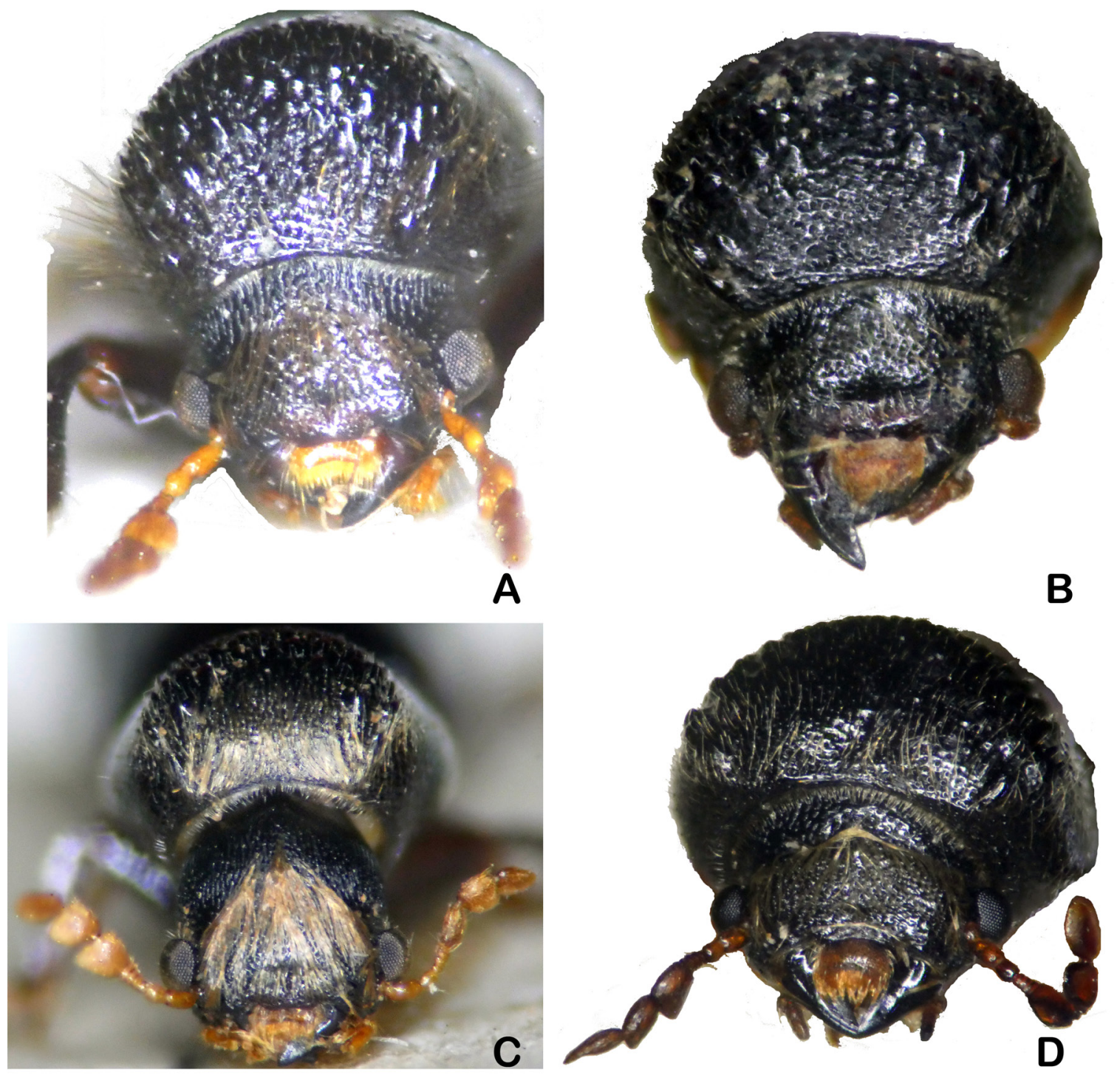

Fig. 2. Frontal view of the females of species of Xylopertha Guérin-Méneville, 1845. A. Xylopertha retusa (Olivier, 1790). B. X. praeusta (Germar, 1817). C. X. elegans sp. nov. D. X. reflexicauda (Lesne, 1937). Scale bar $=1 \mathrm{~mm}$. 
sides moderately to broadly rounded, converging more strongly anteriorly, posterior angles broadly rounded, without a lateral carina, postero-lateral area with fine rugulosities; disc smooth, shining, indistinctly punctured, glabrous; anterior slope with 3 or 4 large, upcurved teeth antero-laterally on each side behind the marginal tooth, with smaller teeth between them.

ScutelLum. Small, tongue-shaped, shining, finely punctured.

ELYTRA. Subequal to pronotum in width, strongly convex, shining, strongly, rather evenly punctured on disc, glabrous anteriorly, the declivity usually strongly sexually dimorphic (Fig. 1A-F).

Legs. Subequal in length, procoxae contiguous, mesocoxae narrowly separated, protibiae grooved on external face, widened to apex, posterior tibiae with long hairs on outer side. Second and third segments of tarsi usually distinctly wider than the following segments.
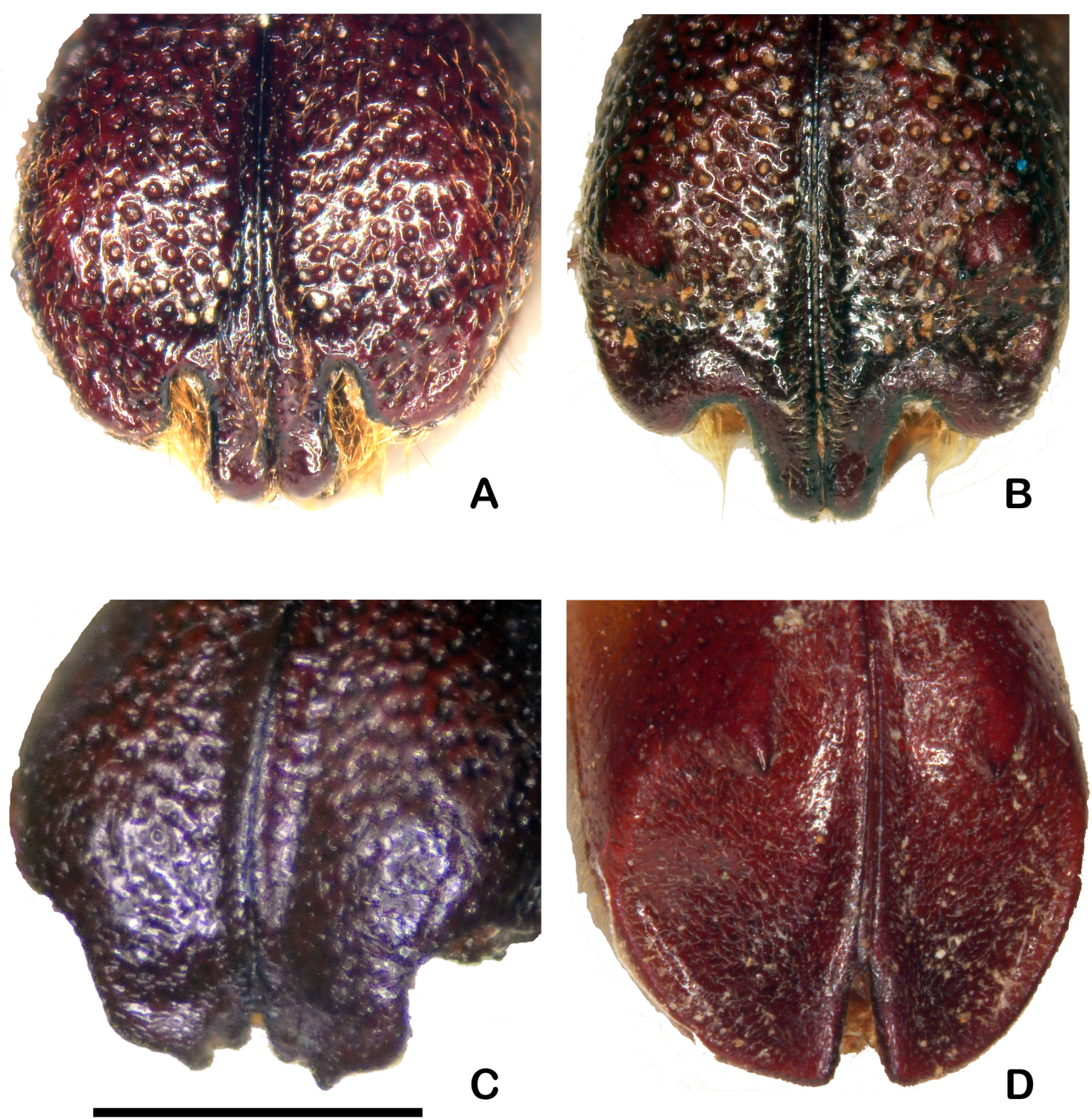

Fig. 3. Declivity of the females of species of Xylopertha Guérin-Méneville, 1845. A. Xylopertha retusa (Olivier, 1790). B. X. praeusta (Germar, 1817). C. X. elegans sp. nov. D. X. reflexicauda (Lesne, 1937). Scale bar $=1 \mathrm{~mm}$. 
AвDOMEN. Intercoxal process of first abdominal ventrite lamelliform, the ventral face a little widened in one species (X. praeusta (Germar, 1817)).

\section{Sexual dimorphism}

The genus shows strong sexual dimorphism in both the vestiture of the frons, and in the form and sculpture of the elytral declivity (except in X. reflexicauda), as well as in the genitalia. In the female the frons is more densely and finely punctured, and the upwardly directed hairs are much longer and denser than in the male. In the male, the elytral declivity is more angularly separated from the disc, and the elytral apices are either conjointly rounded or separated by a small V-shaped emargination. In the female, the disc curves more evenly into the declivity, and the elytral apices are strongly emarginate, the emargination partly filled by a pair of ventrally-directed processes (Fig. 3A-C) (except in X. reflexicauda; Fig. 3D). The last abdominal ventrite of the male has pleural pieces which converge posteriorly towards the midline; these are absent, and the last ventrite is emarginate in the female.

\section{Distribution}

Southern and central Europe, North Africa and Middle East.

\section{Biology}

The adults of Xylopertha are polyphagous, usually attacking a taxonomically wide variety of host trees, although they may appear to show some host preferences. They bore into twigs and branches, where they construct a short gallery, usually consisting of a circumferential and one or more longitudinal branches in which the eggs are laid (Liu et al. 2008). The larvae bore through the wood making extensive galleries filled with fine wood particles and excreta. The new generation of adults emerges through the bark, but may reattack the same stem, so that the whole of the sapwood is eventually converted into fine powder
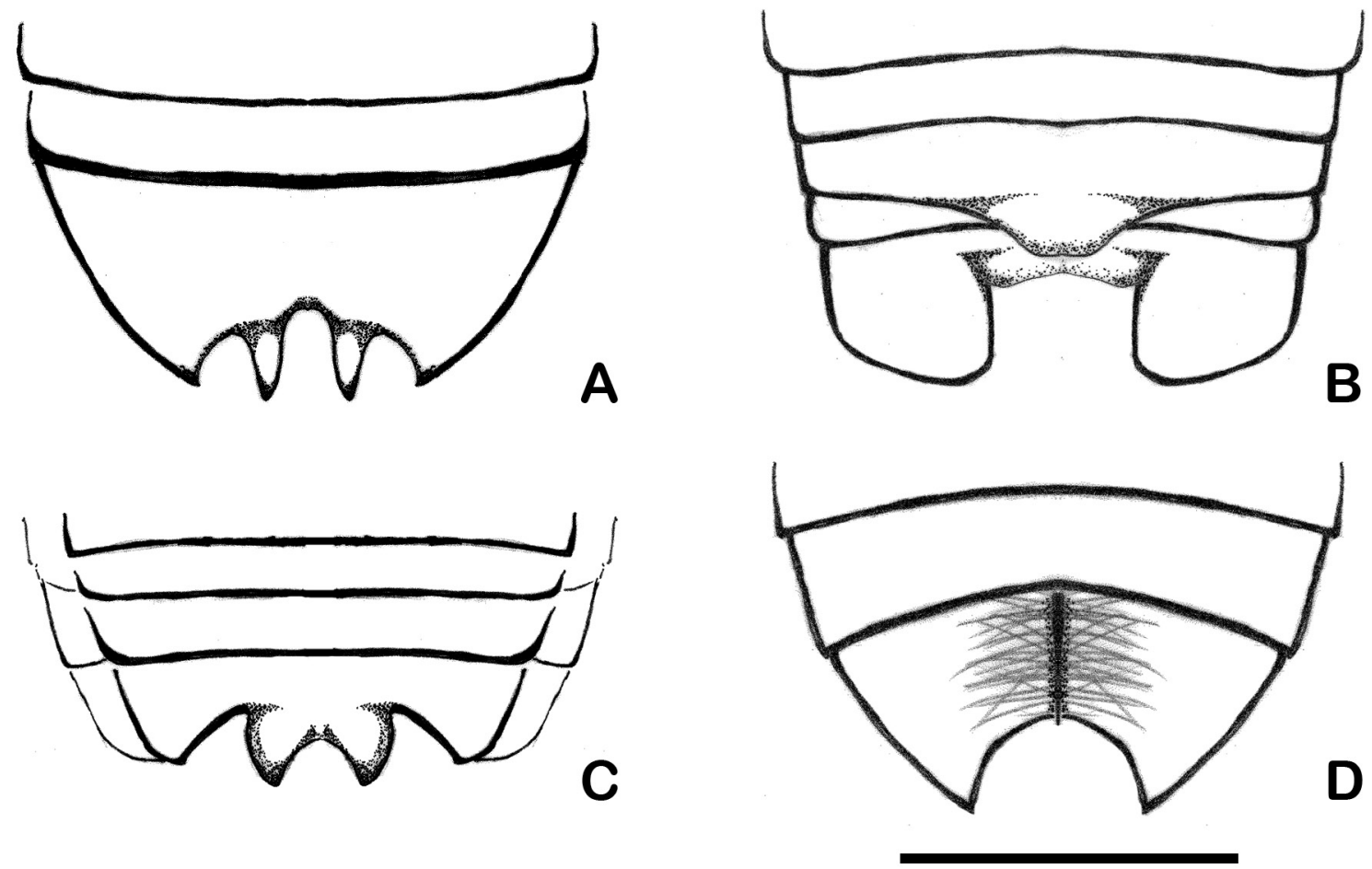

Fig. 4. Last 3 or 4 visible abdominal ventrites of females of species of Xylopertha Guérin-Méneville, 1845. A. Xylopertha retusa (Olivier, 1790). B. X. elegans sp. nov. C. X. praeusta (Germar, 1817). D. $X$. reflexicauda (Lesne, 1937). Scale bar $=1 \mathrm{~mm}$. 
(Liu et al. 2008). The development time is variable depending on local conditions, and may vary from a few weeks to over a year (Beeson \& Bhatia 1937).

Xylopertha elegans sp. nov. urn:1sid:zoobank.org:act:E4831142-6943-4892-8A65-B8AC0C2659D8

Figs $1 \mathrm{~A}-\mathrm{B}, 2 \mathrm{C}, 3 \mathrm{C}, 4 \mathrm{~B}, 5 \mathrm{E}-\mathrm{F}$

Amongst the bostrichid collection in the Staatliche Naturhistorische Sammlungen, Dresden (now Senckenberg Naturhistorische Sammlungen, Dresden), the senior author found a series of specimens identified as a new species of Xylopertha by J.M. Vrydagh, but not described. Further specimens were found in the Museum für Naturkunde, Berlin. This species is described here using the specific name suggested by Vrydagh.

\section{Etymology}

The specific epithet 'elegans' used by Vrydagh, is from the Latin word for 'elegant' or 'handsome'.

\section{Material examined}

Vrydagh selected a holotype, allotype and four paratypes from SNSD, and one paratype from ZMHB. However, the holotype and allotype he selected are in poor condition, and we have accordingly selected a new holotype and allotype in better condition from the same series.

\section{Holotype}

TURKEY: $\widehat{\jmath}$, [Anatolia, Toros, Karaman, Habiller], (no date), [Muche leg.] (ZMHB).

\section{Allotype}

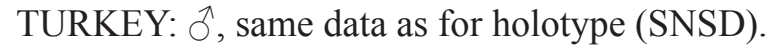

\section{Paratypes}

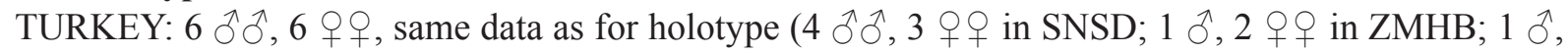
19 in LYL).

\section{Description}

Male

Body. 4-5 mm long, about 3.5 times as long as wide. Head, pronotum and ventral side black, elytra dark reddish brown, antennae, mid- and hind-legs paler.

HEAD. Clypeus finely punctured, with a pair of small rounded projections on either side of mid-line, slightly emarginate laterally. Fronto-clypeal suture distinct, with a median fovea. Frons simple with sparse, fine punctures, each puncture with an upwardly-directed short hair, a pair of very long hairs on each side near the eyes directed towards the midline. Antennae 9-segmented, segments 3-6 together slightly shorter than last segment of club, first and second segments of club slightly wider than long, with small, indistinct areas of dense sensillae, third segment more elongate, and longer than previous segments, without areas of dense sensillae.

Pronotum. About 1.1 times wider than long, anterior margin slightly concave, sides quite strongly rounded, widest in basal third, anterior slope quite strongly granulate-punctate in middle above head, without long hairs antero-laterally, disc shining, with very sparse, fine punctures bearing very short hairs.

Scutellum. Tongue-shaped. 

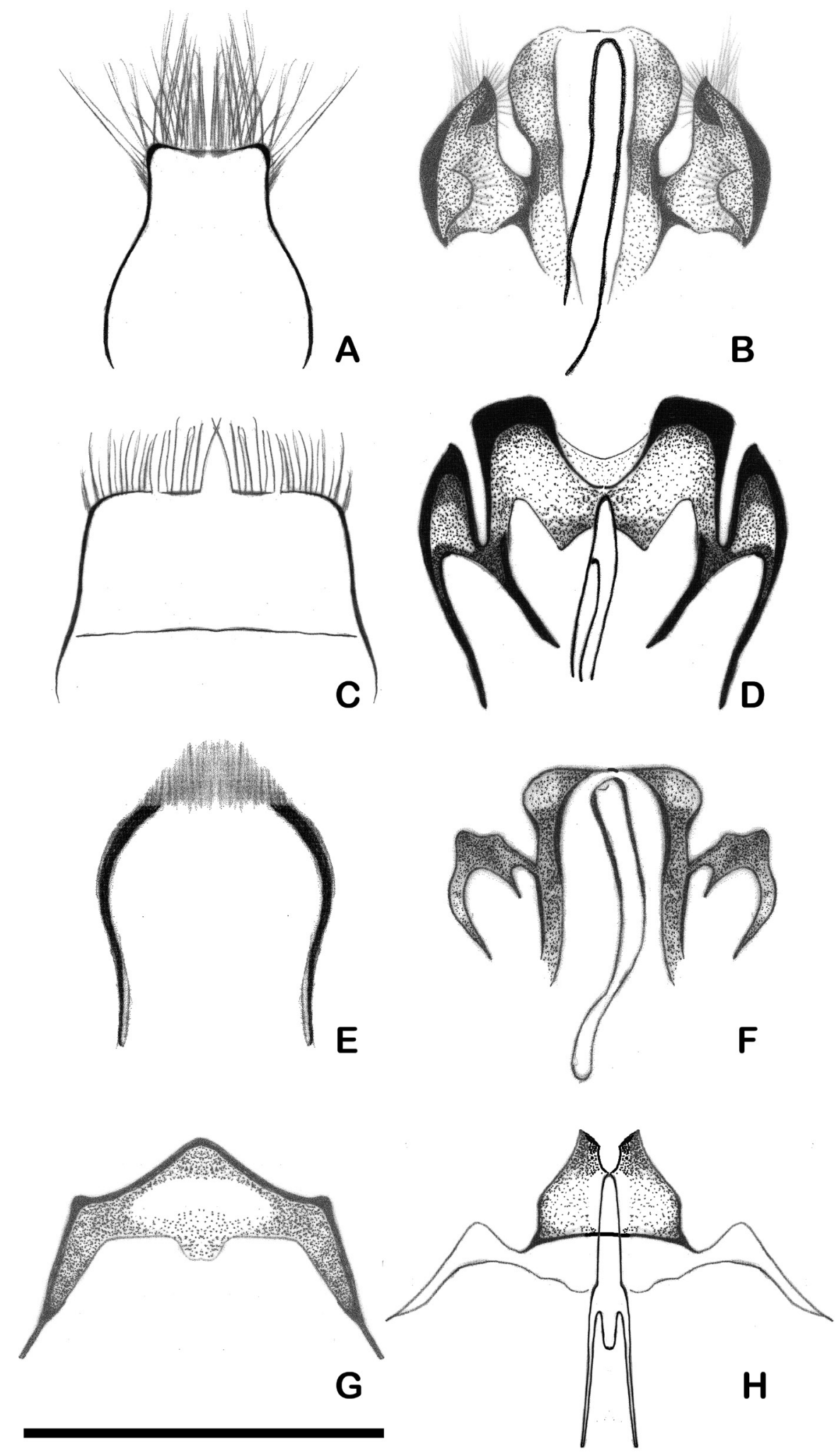

Fig. 5. Male $8^{\text {th }}$ tergite, $5^{\text {th }}$ ventrite and aedeagus of species of Xylopertha Guérin-Méneville, 1845. A. Xylopertha retusa (Olivier, 1790), $8^{\text {th }}$ tergite. B. X. retusa (Olivier, 1790), $5^{\text {th }}$ ventrite and aedeagus. C. X. praeusta (Germar, 1817), $8^{\text {th }}$ tergite. D. X. praeusta (Germar, 1817), $5^{\text {th }}$ ventrite and aedeagus. E. X. elegans sp. nov., $8^{\text {th }}$ tergite. Figure F. X. elegans sp. nov., $5^{\text {th }}$ ventrite and aedeagus. G. X. reflexicauda (Lesne, 1937), $8^{\text {th }}$ tergite. H. X. reflexicauda (Lesne, 1937), $5^{\text {th }}$ ventrite and aedeagus. Scale bar $=1 \mathrm{~mm}$. 
ELYTRA. 2.5-2.8 times longer than wide, parallel-sided, shining, disc and sides with confused, dense, moderately strong punctures, bearing minute hairs; declivity commencing a little behind middle, angularly separated from disc, its upper margin without long, erect hairs, the upper part almost flat, a weak transverse convexity just below middle, apical part weakly concave, the apex strongly extended, a short V-shaped emargination separating the pointed elytral apices, declivital margins forming a distinct rim at the sides and apex, puncturation and vestiture similar to disc, the suture raised in middle part of declivity (Fig. 1A).

LeG. Anterior tibiae broadly grooved on external face. Second and third segments of tarsi distinctly wider than the following segments.

AвDOMEN. Abdominal ventrites finely, moderately densely punctured, the punctures with moderately long, whitish hairs; fifth ventrite with large pleural pieces, converging strongly towards apex of ventrite. Aedeagus simple, without long apophyses (Fig. 5E-F).

\section{Female}

BoDy. Generally similar to male, but differentiated as follows.

HEAD. Clypeus and frons more densely punctured, the punctures with very long yellowish hairs directed towards vertex and partly concealing surface.

PRonotum. Anterior face of pronotum wider, very densely, finely punctured, above the head the punctures with very fine, very long, upwardly directed hairs, discal punctures slightly larger and denser.

ELYTRA. 2.6-2.9 times as long as wide, elytral puncturation coarser and denser, disc gradually curving into declivity in apical quarter, declivity very steep, deeply grooved on either side of the raised suture (Fig. 1B), the sides gibbous without a spine or tubercle, the apex of each elytron projecting as a broad approximately rectangular process, its apex with a small pointed tooth next to the suture, the processes separated by a shallow U-shaped emargination, a broad emargination lateral to each process, the edge of the emargination with a fringe of short hairs (Fig. 3C).

ABdomen. Abdominal $3^{\text {rd }}$ ventrite projecting medially over $4^{\text {th }}$ ventrite, which is only visible at sides, $5^{\text {th }}$ ventrite very deeply, broadly emarginate, the base of the emargination projecting ventrally as a thin lamina behind the process on the $3^{\text {rd }}$ ventrite and concealing the middle part of the $4^{\text {th }}$ ventrite (Fig. 4B).

\section{Distribution}

Central Turkey (Anatolia).

Xylopertha reflexicauda (Lesne, 1937)

Figs $1 \mathrm{G}-\mathrm{H}, 2 \mathrm{D}, 3 \mathrm{D}, 4 \mathrm{D}, 5 \mathrm{G}-\mathrm{H}$

Xylonites reflexicauda Lesne, 1937: 199.

Paraxylogenes pistaciae Damoiseau, 1968: 4, syn. nov.

Xylopertha reflexicauda - Borowski \& Węgrzynowicz 2007: 145.

Paraxylogenes reflexicauda - Buse et al. 2013: 690, 692.

Damoiseau (1968) erected the genus Paraxylogenes for five specimens collected in Iraq and Pakistan in the wood of pistachio trees (Pistachia vera). The genus is monobasic with P. pistaciae Damoiseau, 1968 
being the only species. Damoiseau (1968) separated the genus from four other genera of Xyloperthini with species having nine antennomeres, but failed to compare it with Xylopertha.

We have examined male and female syntypes of Xylopertha reflexicauda from Pakistan (MNHN), the holotype male, allotype female, and three female paratypes of Paraxylogenes pistaciae from Iraq and Pakistan (NHMUK, IRSNB), and further specimens from South Europe and Middle Asia in LYL, NMPC and IRSNB. It is clear that only a single species is represented, and P. pistaciae is here synonymised with $X$. reflexicauda. Buse et al. (2013) listed $P$. pistaciae as a synonym of Paraxylogenes reflexicauda [sic] in a paper on the ecology of oak wood-inhabiting beetles in Israel, but made no further comments, and gave no indication that they had examined type material. The synonymy of the only species of Paraxylogenes with $X$. reflexicauda automatically makes Paraxylogenes a synonym of Xylopertha.

We note below that the male and female genitalia of $X$. reflexicauda differ in several respects from those of the other species of Xylopertha. However, we do not consider these and other morphological differences sufficient to retain Paraxylogenes as a distinct genus from Xylopertha.

\title{
Diagnosis
}

Distinguished from Xylopertha elegans sp. nov. and X. retusa (Olivier, 1790) by the presence of a spine on each elytron in both sexes, the spines smaller in the female. Xylopertha reflexicauda differs from X. praeusta in the position of the spines, which are located on the middle of the upper margin of the declivity in X. reflexicauda, whereas in X. praeusta they are located on the dorso-lateral margin of the declivity (Fig. 1E-H). Xylopertha reflexicauda is also distinguished from the other three species of Xylopertha by the absence of any sexual modification of the apical margin of the elytra. The male and female genitalia differ in certain respects from those of the other three species. The posterior margin of the 8th tergite of the male is sclerotised in X. reflexicauda (Fig. 5G), but membraneous in the other three species (Fig. 5A, C, E). The posterior margin of the last ventrite of the male is bidentate without a median lobe in $X$. reflexicauda (Fig. $5 \mathrm{H}$ ), but has a median lobe and a process on either side in $X$. elegans sp. nov. (Fig. 5F) and X. retusa (Fig. 5B). In X. praeusta (Fig. 5D), the posterior margin is bilobed and lateral processes are present. The aedeagus of $X$. reflexicauda has a pair of long apophyses (Fig. 5H), but the apophyses are absent in the other three species (Fig. 5B, D, F). The last ventrite of the female of $X$. reflexicauda has a strong median ridge (Fig. 4D), which is absent in the other three species (Fig. 4A-C).

\section{Material examined}

For Xylopertha reflexicauda (Lesne, 1934):

\section{Syntypes}

IRAN: 1 ગૈ, 1 \&, [Sud Iran, Prov. de Kirman, Krausseri, Env. de Rafssindjan, Kaussceri 1937.] (MNHN).

For Paraxylogenes pistaciae Damoiseau, 1968:

\author{
Holotype \\ IRAQ: §, [Mosul, B 5.2, 10 May 1965, H. Knopf leg.] (NHMUK).
}

\footnotetext{
Allotype

PAKISTAN: + , [Shingarh, ex Pistacia wood, 29 Aug. 1957, F. Entomologist leg.] (NHMUK).

Paratypes

IRAQ: 1 q, [Mosul, 22.v.1965, Pistacia, 52, F. Shalaly leg.] (NHMUK); 1 \&, [Nenava, 9 May 1965, breeding, Pistacia, 52, F. Shalaly leg.] (IRSNB).
} 
PAKISTAN: 1 ㅇ, [Shingarh, ex Pistacia wood, 29 Aug. 1957, F. Entomologist leg.] (IRSNB).

\section{Additional material}

GREECE: 1 + , [Crete, Amudarion, 1983, M. Siáma leg.] (LYL) (New record for Greece).

IRAN: $2 \widehat{\partial}, 1$ ㅇ, [Prov. Tehran, Karaj, University of Agriculture, $35^{\circ} 47^{\prime} 97^{\prime \prime} \mathrm{N}, 51^{\circ} 00^{\prime} 25^{\prime \prime} \mathrm{E}, 1360 \mathrm{~m}$, 30 Apr. 2010, A. Skale leg.]; 2 우, same data as previous, [\#10, A. Weigel leg., ex Salix]; 1 ภ, 1 , [Kaschan, May1960, A. Davatchi leg.] (all LYL).

The specific identity of more than 70 further specimens was checked in the following museums: IRSNB and MAIC under X. reflexicauda; NHMUK and NMPC under Paraxylogenes pistaciae, but detailed locality data were not recorded. All specimens came from the distributional area given below.

\section{Description}

Body. 5-7 mm long, about 2.8-3.0 times as long as wide, subelongate, parallel-sided. Head, prothorax, scutellum, metasternum and abdomen black, elytra reddish anteriorly, black posteriorly, antennae and legs reddish, anterior tibiae brown.

HeAd. Above finely punctured, with erect, grey or reddish setae (denser and longer in female), eyes moderate, similar in both sexes; antennae 9-segmented, segments 3-6 very small, 7-9 forming the club, biconvex, subglabrous, sensory impressions scarcely visible, penultimate segment slightly transverse.

Pronotum. Subquadrate, about 1.1 times wider than long, the sides weakly curved, widest at middle, with long hairs antero-laterally, anterior angles armed with small, sharp-edged and pointed teeth, the apex not uncinate; posterior part of disc very finely, sparsely punctured.

ELYTRA. Cylindrical part glabrous, fairly strongly punctured (in male sometimes weaker); apical declivity minutely punctured, with dense, recumbent, very short hairs; elytral declivity with a inflated, sharply pointed spine located on the middle of upper margin of the declivity of each elytron (Figs 1G-H, 3D); elytral suture cariniform on declivity; apical margin entire, sutural angles prominent, reflexed, forming a v-shaped emargination, blunt at apex; postepipleura absent.

\section{Male}

ELYTRA. Apical declivity of elytra without large punctures, lateral margin subcarinate.

ABdomen. Last ventrite whole, pleural parts very distinct. The posterior margin of the $8^{\text {th }}$ tergite of the male is sclerotized, margin of the last ventrite of the male is bidentate without a median lobe (Fig. $5 \mathrm{H}$ ). The aedeagus has a pair of long apophyses (Fig. 5H).

\section{Female}

ELYTRA. Apical declivity of elytra with larger punctures in upper part, laterally not marginate, spines on upper margin smaller than in male, apical margin entire.

AвDOMEn. The last ventrite with a deep incision apically, anterior to the incision a very short, high, longitudinal carina, its summit knife-like, its sides with very long, stiff, red setae standing perpendicular to the carina (Fig. 4D), the surface of the sternite with similar hairs.

\section{Distribution}

Israel, Iraq, Iran, Pakistan, Greece (Crete). Intercepted in Australia (PaDIL 2014) and Charleston, SC, USA (NMNH). 


\section{Biology}

Recorded from pistachio tree wood (Pistacia vera L. (Anacardiaceae R. Br.)) in Iraq, Iran and Pakistan (Lesne 1937; Damoiseau 1968; Halperin 1986; Modarres Awal 1997), and this species appears to be its usual host. It is a secondary pest of pistachio in Israel (Halperin 1986). The species is also recorded in Iran from Quercus sp. (Fagaceae Dumort), Ficus carica L., Morus alba L. (Moraceae Link) (Modarres Awal 1997), and Salix sp. (Salicaceae Mirb.), and in Pakistan from Prosopis cineraria (L.) Druce (= spicigera) (Fabaceae Lindl.) (Lesne 1937). Gerstmaier et al. (1999) record Denops albofasciatus (Charpentier, 1825) (Coleoptera, Cleridae) as a predator in Israel.

\section{Xylopertha retusa (Olivier, 1790)}

Figs 1C-D, 2A, 3A, 4A, 5A-B

Bostrichus retusus Olivier, 1790: 110.

Apate sinuata Fabricius, 1792: 362. Synonymy: Schilsky 1899: 291.

Apate aterrimus Faldermann, 1837: 250. Synonymy: Lesne 1901: 578.

Xylonites retusus - Lesne 1901: 577.

Xylopertha retusa - Fisher 1950: 143.

Type material of X. retusa was not located, but the species is well-known in the Mediterranean area, and the senior author has examined numerous specimens determined by Lesne, Vrydagh and others in IRSNB, LYL, MAIC, MIZPAN, MNB, MTM, NHMUK, NMBS, NMPC, NMS, NMW, SDEI, SNSD, ZMHB and ZSM, mainly from North Africa, South and Central Europe, Turkey, and Iran.

\section{Diagnosis}

The species is easily separable from $X$. praeusta and $X$. reflexicauda by the absence of spines on the elytra in both sexes. The male can be separated from $X$. elegans sp. nov. by the presence of long, erect hairs on the upper margin of the elytral declivity (absent in X. elegans sp. nov.), and by the form of the $8^{\text {th }}$ tergite and genitalia (Fig. 5A-B: X. retusa; Fig. 5E-F: X. elegans sp. nov.). In the female of X. retusa, the apex of each elytron is strongly emarginate, the emargination filled by a pair of ventrally-directed processes with rounded tips next to the suture (Fig. 3A); in X. elegans sp. nov., the apex of each elytron projects as a broad, approximately rectangular process, its apex with a small pointed tooth next to the suture, the processes separated by a shallow U-shaped emargination, a broad emargination lateral to each process (Fig. 3C). In the female of $X$. retusa, the fourth ventrite is visible across its entire width, and the base of the emargination of the $5^{\text {th }}$ ventrite does not project ventrally (Fig. 4A); in X. elegans sp. nov., the $3^{\text {rd }}$ abdominal ventrite projects medially over the $4^{\text {th }}$, which is visible only at the sides, and the $5^{\text {th }}$ ventrite is very deeply, broadly emarginate, the base of the emargination projecting as a thin lamina behind the process on the $3^{\text {rd }}$ ventrite (Fig. 4B).

\section{Material examined}

AUSTRIA: 1 đ , 1 q, [Mistelbach, 16 May 1992, Schillhammer leg.]; 1 ô, [A.B. Leche, Seewinkel, Apr. 1967, Holzschuh leg.] (LYL).

BELGIUM: 1 q, [Yvoir, 7 Jul. 1946, A. Collart leg.] (LYL, more than 50 in IRSNB from South Europe).

CZECH REPUBLIC: 1 + , [Bohemia, Dievic Dřevíč, 8 Jun. 1995, P. Zahradnik leg.] (LYL, 80 more in NMPC).

FRANCE: 1 O, 1 q, (no locality); 1 q, (no locality), [deciduous forest, \#51, I.G. 19.501]. 
MACEDONIA: 1 ô, [10 km N of Struga, 4 Jun. 1992, Zbaždi, P. Zahradnik leg.] (LYL).

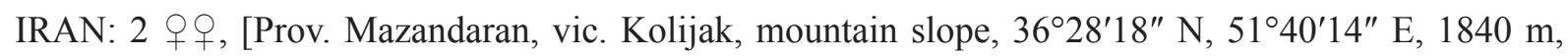
5 May 2010, A. Weigel leg. \#22a.] (1 $q$ in LYL, 1 in NME).

The specific identity of more than 800 further specimens was checked in the following museums: IRSNB, MAIC, MIZPAN, MNB, MTM, NHMUK, NMBS, NMPC, NMS, NMW, SDEI, SNSD, ZNHB and ZSM, but detailed locality data were not recorded. All specimens came from the distributional area given below.

\section{Description}

BoDy. 3-6 mm long, about 2.8-3.0 times as long as wide, elongate. Black or dark brown, moderately shiny, antennae and tarsi reddish, the posterior part of the elytra often paler.

HeAD. Clypeus finely and densely punctured, not convex in front. Frons with puncturation less fine and less dense than the clypeus, slightly rough, and covered by fairly long, fine pubescence directed upwards. First and second segments of antennal club as wide as long.

Pronotum. Slightly wider than long, fairly strongly narrowed in the anterior third, bearing golden, long, erect pubescence on the anterior angles; area above head finely and more or less roughly punctured; median and posterior areas shiny with fine, sparse puncturation; sides evenly rounded; posterior angles rounded; widest in basal part.

ELYTRA. 1.8-2.2 times longer than wide, parallel-sided at disc and widest at middle of declivity. Elytral disc moderately dense puncturation, not coarser posteriorly. Upper margin of the elytral declivity bearing reddish, quite long erect pubescence, denser in the male. Elytral suture projecting on declivity, more strongly towards the apex. Elytral declivity without spines on each elytron in both sexes.

Legs. External face of the anterior tibiae broadly grooved, not narrowed towards the apex. Segments 2 and 3 of anterior tarsi distinctly wider than the others.

\section{Male}

ELYTRA. Widened posteriorly. Upper margin of elytral declivity bearing long, erect pubescence. Elytral suture not raised on disc, strongly raised on declivity. Declivity rather finely punctured in the upper half, almost impunctate below, sometimes transversely ridged on much of its surface. Apical declivity larger than in female, more sharply truncate, a little concave, bordered on the lower-lateral side by a carina not extending to the sutural angle, the carina expanded at the sides of the declivity to form a marginal callus. Sutural angles pointed, conjointly projecting or weakly separated at the apex (Fig. 1C-D).

ABDOMEN. Anterior margin of $8^{\text {th }}$ tergite fringed by long erect outwardly directed hairs. Genitalia strongly sclerotised, with extended lobes laterally, fringed with long hairs at apex and on a small inwardly projecting lobe towards base on each side. Aedeagus simple, without long apophyses (Fig. 5A-B).

\section{Female}

HEAD. Frons covered by longer, denser upwardly directed hairs than in male.

ELYTRA. Parallel, suture strongly raised on declivity. Declivity strongly and densely punctured with a truncate raised area at apical third. Lateral margin of declivity sinuate. Apex of each elytron strongly emarginate, the emargination filled by a pair of ventrally-directed processes with rounded tips next to suture (Fig. 3A). 
ABDOMEN. Third abdominal ventrite not projecting medially over $4^{\text {th }}$, which is visible across its entire width; 5th segment longer than 2 to 4 together, strongly, longitudinally grooved in the middle, and provided on its posterior margin with two large teeth, contiguous at the base, strongly pointed, and slightly recurved dorsally near the apex; on the outer side of the teeth the posterior margin of the segment is semicircularly emarginate (Fig. 4A).

\section{Distribution}

Central and southern Europe, North Africa (except Egypt), Cyprus, Israel, Turkey, Iran, part of Caucasia and Siberia (Liu et al. 2016b).

\section{Biology}

The species has been recorded from the wood of trees in the families Fabaceae, Fagaceae, Moraceae, Ulmaceae Mirb. and Vitaceae Juss. (Lesne 1901; Bahillo de la Puebla et al. 2007; Marković \& Stojanović 2012; Buse et al. 2013). The species is active from May to July in Southern Europe (Cymorek 1961 as Xylonites retusus; Bahillo de la Puebla et al. 2007), but from October to December in Israel (Buse et al. 2013). In Central Europe, the beetles prefer boring into dry oak branches; the larvae tunnel particularly in the sapwood; they overwinter in diapause and pupate in spring (Cymorek 1961 as Xylonites retusus). Several clerid and a melyrid predators (Coleoptera: Cleridae, Melyridae) are listed by Bahillo de la Puebla et al. (2007). Yu et al. (2012) list three species of braconid Hymenoptera as parasitoids.

\section{Xylopertha praeusta (Germar, 1817)}

Figs 1E-F, 2B, 3B, 4C, 5C-D

Apate praeusta Germar, 1817: 226.

Xylopertha appendiculata Lucas, 1849: 466. Synonymy: Jacquelin du Val 1860: 164.

Xylopertha dunensis Rai \& Chatterjee, 1964: 122. Synonymy: Borowski \& Singh 2017: 198.

Xylonites praeustus - Lesne 1901: 581.

Xylopertha praeusta - Rai \& Chatterjee 1964: 124.

The type material of X. praeusta was not located, but the species is well known in the Mediterranean area. The senior author has examined numerous specimens determined by Lesne and Vrydagh, and numerous other specimens in IRSNB, LYL, MAIC, MNB, NHMUK, SDEI, SNSD and ZMHB, from various countries in southern Europe and North Africa. Borowski \& Singh (2017) examined the type series of Xylopertha dunensis deposited in IFRI, and synonymised $X$. dunensis with $X$. praeusta. They state that the specimens in the type series came in fact from Tulon [sic] (correctly Toulon), S-France. It has become apparent that $\mathrm{K}$. Rai falsified the type location of several species that he described (Borowski \& Singh 2017). India should, therefore, be excluded from the distribution of $X$. praeusta. If the species does occur in India, it is almost certainly introduced.

\section{Diagnosis}

The species is distinguished from $X$. elegans sp. nov. and $X$. retusa by the presence of a spine on each elytron in both sexes (Fig. 1). It is distinguished from $X$. reflexicauda by the position of the spine, which is on the dorso-lateral margin of the declivity in X. praeusta, but on the middle of the upper margin of the declivity in $X$. reflexicauda. Differences in the abdomen and genitalia are illustrated in Figs 4 and 5.

\section{Material examined}

ITALY: 1 ○, [Corsikac. Ug., Corte, 28 May 20, 11, F/o Bmann, Tavignano-Tal] (NME). 
FRANCE: 1 ô, 1 q, [Larale Valley, Pyrenees, J. Kettere leg.]; 1 q, [A. Melie L/B, LE/5-6-1960, ex coll. A. Jacobs (IG: 28.548)].

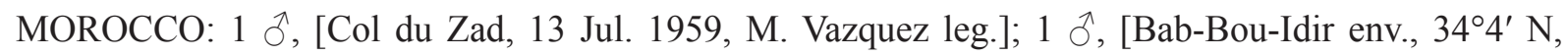
47’ W, 28 May-3 Jun. 1999, Tazzeka N.P., I. Smatana leg.] (LYL).

The specific identity of more than 260 further specimens was checked in the following museums: IRSNB, MAIC, MIZPAN, MNB, MTM, NHMUK, NMBS, NMPC, NMS, NMW, SDEI, SNSD, ZNHB and ZSM, but detailed locality data were not recorded. All specimens came from the distributional area given below.

\section{Description}

BoDy. 4-8 mm long, about 2.5-2.8 times as long as wide, stout, parallel-sided. Body shiny, head, pronotum, ventral side and femora black; elytral disc dark brown, darker toward the declivity; tibiae dark brown, antennae and tarsi paler.

HEAD. Clypeus finely and densely punctured, convex along its anterior margin, its median truncation as wide as base of labrum. Frons with puncturation less dense than clypeus, covered by fairly long, upwardly directed hairs. First and second segments of antennal club slightly elongate. Fifth antennal segment often nicked on external side, but this is not constant, nor particular to one sex. Pronotum about 1.1 times wider than long, narrowed in anterior third, without long hairs antero-laterally, area above the head finely punctured.

ELYTRA. Puncturation dense and strong on whole of disc; elytral declivity with a tubercle-like spine with a pointed apex located on dorso-lateral margin of declivity of each elytron (Figs 1E-F, 3B); pubescence of apical declivity short, erect, reddish, especially noticeable near upper margin where formed of longer hairs.

LEGS. External face of anterior tibiae narrowly grooved, widened to apex. Second and third segments of anterior tarsi scarcely wider than the following ones.

\section{Male}

ELYTRA. Apical declivity larger than in female, covered by an exceedingly fine and dense puncturation, and often wrinkled in its upper part; elytral spine robust, directed inwardly, strongly bulbous on outer side at base, narrow and very pointed at apex, below it a broad flange beginning at sutural angle and extending at sides to about level of lateral spine; sutural angles not projecting, rounded at apex (Fig. 1E).

Abdomen. Anterior margin of $8^{\text {th }}$ tergite wider and fringed by shorter erect hairs than in $X$. retusa. Genitalia more strongly sclerotised than in $X$. retusa, with pair of ventrally-directed processes with pointed tips next to inner lobes which are separated by a U-shaped emargination in middle. Aedeagus simple, without long apophyses (Fig. 5C-D).

\section{Female}

ELYTRA. Declivity less distinctly truncate than in the male, strongly punctured, the lateral spines smaller, or replaced by tubercles; suture inflated on the declivity (Fig. 1F). Apical emargination of elytra broad, the emargination largely filled by a pair of ventrally-directed, extended processes with rounded tips next to suture (Fig. 3B).

ABDomen. Last visible segment of abdomen densely pubescent on sides, not grooved in middle; posterior margin of segment armed by two dorsally recurved large median teeth (Fig. 4C). 


\section{Distribution}

Southern Europe, North Africa, Israel, Turkey.

\section{Biology}

The species has been recorded from the following genera and families of trees: Viburnum L. (Adoxaceae E.Mey.), Mangifera L., Pistacia (Anacardiaceae), Acacia Mill. (Fabaceae), Castanea Mill., Quercus L. (Fagaceae), Ficus L. (Moraceae), Eucalyptus L'Hér. (Myrtaceae Juss.), Populus L. (Salicaceae), Vitex L. (Vitaceae Juss.) (Lesne 1901; Rai \& Chatterjee 1964; Akşit et al. 2005; Buse et al. 2013). However, it develops primarily in oaks (Quercus) (Bahillo de la Puebla et al. 2007; Nardi \& Mifsud 2015). In Europe, adults emerge in May-July (Lesne 1901), but are active until November in Israel (Buse et al. 2013). The species has diurnal habits. The gallery system is typical of the genus. Larvae overwinter and complete their development in the spring of the following year (Lesne 1901).

\section{Key to species of Xylopertha}

1. Elytral declivity with a spine on each elytron in both sexes (Fig. 1E-H) $\ldots \ldots \ldots \ldots \ldots \ldots \ldots \ldots \ldots \ldots \ldots \ldots \ldots \ldots \ldots \ldots \ldots$

- Elytral declivity without spines in both sexes (Fig. 1A-D) ...............................

2. Tubercle-like spine with a pointed apex located on the dorso-lateral margin of the declivity of each elytron (Figs 1E-F; 3B). Male: $8^{\text {th }}$ tergite and genitalia as in Fig. 5C-D. Female: last four abdominal ventrites as in Fig. $4 \mathrm{C}$

X. praeusta (Germar, 1817)

- Spine located on the middle of upper margin of the declivity of each elytron (Figs 1G-H; 3D). Male: eighth tergite and genitalia as in Fig. 5G-H. Female: last three abdominal ventrites as in Fig. 4D X. reflexicauda (Lesne, 1937)

3. Male: upper margin of elytral declivity without long, erect hairs. The $8^{\text {th }}$ tergite and genitalia as in Fig. 5E-F. Female: apex of each elytron projecting as a broad approximately rectangular process, its apex with a small pointed tooth next to the suture, the processes separated by a shallow U-shaped emargination, a broad emargination lateral to each process (Fig. 3C); $3^{\text {rd }}$ abdominal ventrite projecting medially over $4^{\text {th }}$, which is visible only at sides; $5^{\text {th }}$ ventrite very deeply, broadly emarginate, base of emargination projecting ventrally as a thin lamina behind process on the $3^{\text {rd }}$ ventrite, concealing middle part of $4^{\text {th }}$ ventrite (Fig. 4B) X. elegans sp. nov.

- Male: upper margin of elytral declivity bearing long, erect hairs. The $8^{\text {th }}$ tergite and genitalia as in Fig. 5A-B. Female: apex of each elytron strongly emarginate, the emargination filled by a pair of ventrally-directed processes with rounded tips next to suture (Fig. 3A); $3^{\text {rd }}$ abdominal ventrite not projecting medially over $4^{\text {th }}$, which is visible across its entire width, base of emargination of $5^{\text {th }}$ ventrite not projecting ventrally as a thin lamina (Fig. 4A) $\ldots . . . X$. retusa (Olivier, 1790)

\section{Discussion}

The tribe Xyloperthini has the highest number of genera (33, after the synonymy of Paraxylogenes with Xylopertha) in the whole family Bostrichidae, and often shows characters which are continuously variable amongst genera (Liu \& Schönitzer 2011). The morphological distinctions between some of the genera are slight, and certain genera and species should possibly be synonymised (Liu, personal observations). The tribe includes five genera with nine-segmented antennae: Xylopertha, Enneadesmus Mulsant, 1851, Scobicia, Xylogenes Lesne, 1901, Psicula. However, of these genera, only Psicula appears to be closely related to Xylopertha (see Table 1). Enneadesmus, Scobicia and Xylogenes have clearly delimited circular sensory depressions on the first two segments of the antennal club, the frontal setae are arranged in a crown or in two lateral rows, and the posterior margin of the female elytra is entire. The posterior margin of the fifth ventrite of the female is also entire in Enneadesmus and Scobicia, although emarginate in Xylogenes. In Xylopertha and Psicula, the antennal segments have two indistinct zones of sensory pores, the frontal 


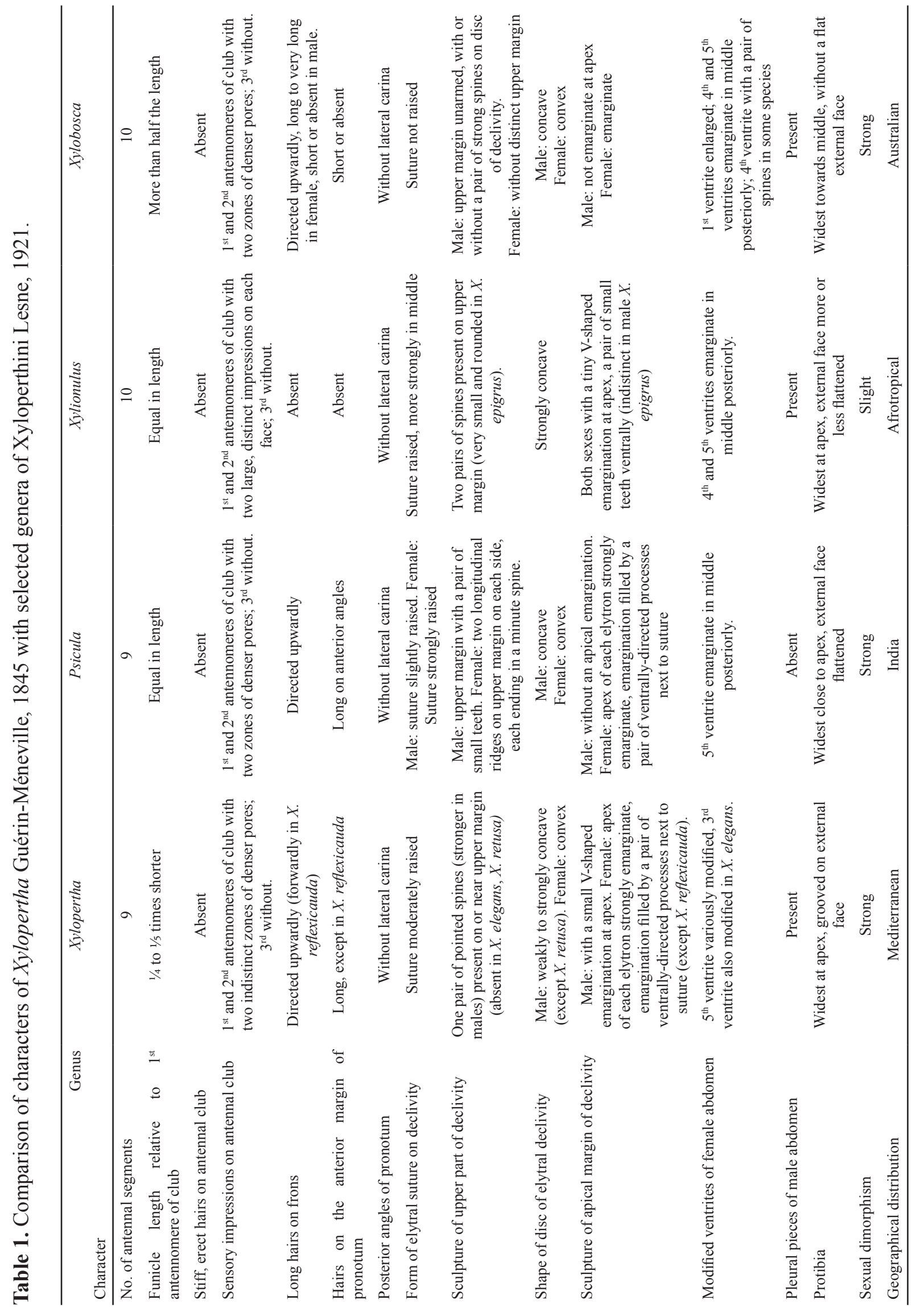


setae cover the whole frons, and are upwardly directed, the posterior margin of the female elytra is strongly emarginate, and the female fifth ventrite is variously modified. It seems likely that Enneadesmus, Scobicia and Xylogenes evolved a nine-segmented antenna independently from Xylopertha and Psicula. Here, we compared the characters of Xylopertha, Psicula and two other genera, Xylobosca Lesne, 1901 and Xylionulus Lesne, 1901, that appear to be related to Xylopertha, in Table 1.

Xylobosca is distinguished from the other genera considered here by the form of the protibia, which is atypical for Xyloperthini, widest towards the middle rather than at the apex, and lacking a flat external face. Xylionulus differs from Xylopertha especially in characters of the antennae, the vestiture of the frons and pronotum, and the lack of strong sexual dimorphism. Psicula is the genus most similar to Xylopertha morphologically (Table 1), with very similar characters of the antennae, frons, pronotum and elytra, but the male lacks the pleural pieces on the fifth abdominal ventrite that are present in Xylopertha. The two genera also have nearly adjacent geographical distributions, Xylopertha extending through the Mediterranean region as far East as Pakistan, and Psicula recorded in North-East India (Sikkim, West Bengal).

The tribe Xyloperthini is greatly in need of revision and further phylogenetic analysis. There are at present no molecular studies of any tribe of Bostrichidae, and much progress may be made in the future using molecular methods. Liu \& Schönitzer (2011) suggest that the tribe Xyloperthini is polyphyletic, but their study included only nine genera. A study including as many genera as possible is needed. The geographical distribution of the tribe covers all zoogeographic regions except the Arctic-Siberian, although most species occur in the Palaearctic and Afrotropical regions. A preliminary analysis of the phylogeography of the family suggests that it originated in Gondwana rather than Laurasia (Liu 2016). The genera currently included in the tribe Xyloperthini appear to have multiple geographical origins (Liu, unpublished), again suggesting polyphyly. The present paper is the second in a larger project which will try to resolve some of these problems.

\section{Acknowledgements}

We appreciate Dr. Michael A. Ivie's comments to improve the paper, and are most grateful to the following curators who have allowed us access to the collections in their charge or who have sent specimens for identification: P. Limbourg (IRSNB), L. Zerche (SDEI), B. Jäger (ZMHB), K-D. Klass (SNSD), A. Taghavian (MNHN), S. Shute, M. Barclay (NHMUK).

\section{References}

Akşit T., Çakmak I. \& Özsemercí F. 2005. Some new xylophagous species on fig trees (Ficus carica cv. Calymirna L.) in Aydýn, Turkey. Turkish Journal of Zoology 29: 211-215.

Bahillo de la Puebla P., López-Colón J.I. \& Baena M. 2007. Los Bostrichidae Latreille, 1802 de la fauna íbero-balear (Coleoptera). Heteropterus Revista de Entomologia 7: 147-227.

Beeson C.F.C. \& Bhatia B.M. 1937. On the biology of the Bostrychidae (Coleopt.). Indian Forest Records, Entomology (New Series) 2: 223-323.

Borowski J. \& Singh S. 2017. Bostrichidae and Ptinidae: Ptininae (Insecta: Coleoptera) type collection at National Forest Insect Collection, Forest Research Institute, Dehradun (India). World Scientific News 66: 193-224.

Borowski J. \& Węgrzynowicz P. 2007. World Catalogue of Bostrichidae (Coleoptera). Wydawnictwo Mantis, Olsztyn.

Buse J., Assmann T., Friedman A.L.L., Rittner O. \& Pavlicek T. 2013. Wood-inhabiting beetles (Coleoptera) associated with oaks in a global biodiversity hotspot: a case study and checklist for Israel. Insect Conservation and Diversity 6: 687-703. https://doi.org/10.1111/icad.12023 
Cymorek S. 1961. Lyctidae \& Bostrychidae. In: A. Horion (ed.) Faunistik der Mitteleuropäischen Käfer, Band VIII, Clavicornia II: 164-188. Ph.C.W. Schmidt, Neustadt a.d. Aisch.

Damoiseau R. 1968. Paraxylogenes, un genre nouveau de Bostrychidae Asiatique (Coleoptera Cucujoidea). Bulletin de l'Institut Royal des Sciences Naturelles de Belgique 44 (5): 1-6.

Fabricius J.C. 1792. Entomologia systematica emendata et aucta. Secundum classes, ordines, genera, species, adjectis synonimis, locis observationibus, descriptionibus. Tome I. Pars II. C.G. Proft, Copenhagen. https://doi.org/10.5962/bhl.title.36532

Faldermann F. 1837. Fauna Entomologica Trans-Caucasica. Pars II. Nouveaux Mémoires de la Société Impériale des Naturalistes de Moscou 5, Imperial Naturalist Society, Moscow.

Fisher W.S. 1950. A revision of the North American species of beetles belonging to the family Bostrichidae. Miscellaneous Publications 698, United States Department of Agriculture, Washington DC. https://doi.org/10.5962/bhl.title.65663

Germar E.F. 1817. Reise nach Dalmatien und in das Gebiet von Ragusa. Brockhaus, Leipzig and Altenburg.

Gerstmaier R., Halperin J. \& Chekatunov V. 1999. An annotated list of Cleridae and Thanerocleridae (Coleoptera) of Israel. Phytoparasitica 27: 26-33. https://doi.org/10.1007/bf02980724

Gorham H.S. 1883. Fam. Bostrychidae. In: Godman F.D. \& Salvin O. (eds) Biologia Centrali-Americana. Insecta, Coleoptera, Malacodermata. Vol. III. Part 2: 210-224. G.H. Porter, London.

Guérin-Méneville F.E. 1845. Note sur quelques coléoptères trouvés dans la racine de Squine (Smilax chine). Bulletin de la Société Entomologique de France, Série 2 3: 16-17.

Halperin J. 1986. New pests of pistachio in Israel. Phytoparasitica 14: 156.

https://doi.org/10.1007/BF02980906

Jacquelin du Val P.N.C. 1860. Remarques et synonymies diverses. In: Glanures entomologiques; ou, recueil de notes monographiques, descriptions, critiques, remarques et synonymies diverses, Cahier 2: 161-164. E. Donnaud, Paris.

Lesne P. 1901. Révision des coléoptères de la famille des Bostrychides. 4e Mémoire. Bostrychinae sens. strict. II. Les Xylopertha. Annales de la Société Entomologique de France 69: 473-639.

Lesne P. 1921. Classification des coléoptères xylophages de la famille des Bostrychides. Compte rendu de l'Association Française pour l'Avancement de Science, 44e Session, Strasbourg 1920: 285289. Available from http://www.biodiversitylibrary.org/item/27278\#page/289/mode/ [accessed 22 Nov. 2017].

Lesne P. 1937. Xyloperthini paléarctiques peu connus ou nouveaux. Bulletin de la Société Entomologique de France 1937: 195-200.

Liu L.-Y. 2016. The faunal elements of Bostrichidae (Insecta: Coleoptera). Poster presented at XXV International Congress of Entomology 25-30 Sep. 2016.

https://esa.confex.com/esa/ice2016/meetingapp.cgi/Paper/110145 [accessed 5 Dec. 2017].

Liu L.-Y., Schönitzer K. \& Yang J.-T. 2008. A review of the literature on the life history of Bostrichidae (Coleoptera). Mitteilungen der Münchener Entomologischen Gesellschaft 98: 91-97.

Liu L.-Y. \& Schönitzer K. 2011. Phylogenetic analysis of the family Bostrichidae auct. at suprageneric levels (Coleoptera: Bostrichidae). Mitteilungen der Münchener Entomologischen Gesellschaft 101: 99-132. 
Liu L.-Y., Beaver R.A. \& Sanguansub S. 2016a. A new Oriental genus of bostrichid beetle (Coleoptera: Bostrichidae: Xyloperthini), a new synonym and a lectotype designation for Octodesmus episternalis (Lesne, 1901). European Journal of Taxonomy 189: 1-12. https://doi.org/10.5852/ejt.2016.189

Liu L.-Y., Ghahari H. \& Beaver R.A. 2016b. An annotated synopsis of the powder post beetles of Iran (Coleoptera: Bostrichoidea: Bostrichidae). Journal of Insect Biodiversity 4 (14): 1-22. https://doi.org/10.12976/jib/2016.4.14

Lucas H. 1849. Exploration scientifique de l'Algérie pendant les années 1840, 1841, 1842, publiée par ordre du Gouvernement et avec le concours d'une Commission Académique. Sciences Physiques. Zoologie. Histoire naturelle des animaux articulés. Part II. Insectes. Imprimerie Nationale. Paris. https://doi.org/10.5962/bhl.title.112444

Marković Č. \& Stojanović A. 2012. Fauna of phloeomo-xylophagous insects, their parasitoids and predators on Ulmus minor in Serbia. Biologia 67: 584-589. https://doi.org/10.2478/s11756-012-0044-7

Modarres Awal M. 1997. Bostrichidae; Lyctidae. In: Modarres Awal M. (ed.) List of Agricultural Pests and their Natural Enemies in Iran: 129-130, 175. Ferdowsi University Press, Mashhad (Iran).

Nardi G. \& Mifsud D. 2015. The Bostrichidae of the Maltese Islands (Coleoptera). ZooKeys 481: 69108. https://doi.org/10.3897/zookeys.481.8294

Olivier A.G. 1790. Bostriche. In: Encyclopédie méthodique, ou par ordre des matières. Histoire naturelle. Insectes, Tome 5: 104-111. Agasse, Paris. https://doi.org/10.5962/bhl.title.82248

PaDIL. 2014. Biosecurity and Biodiversity: protecting against invasive pests and diseases and discovery of native species. The Plant Biosecurity Cooperative Research Centre.

Available from http://www.padil.gov.au/ [accessed 26 Jun. 2016].

Park S., Lee S. \& Hong K.-J. 2015. Review of the family Bostrichidae (Coleoptera) of Korea. Journal of Asia-Pacific Biodiversity 8: 298-304. https://doi.org/10.1016/j.japb.2015.10.015

Rai K. \& Chatterjee P.N. 1964. Studies on the morphology and taxonomy of Indian Bostrychidae. IV. A new species of Xylopertha Guérin-Méneville from North India (Coleoptera: Bostrychidae: Bostrychinae). Indian Forester 90: 122-124.

Schilsky J. 1899. Die Käfer Europas. Nach der Natur beschrieben von Dr. H.C. Küster und Dr. G. Kraatz. Fortgesetzt von J. Schilsky. Sechsunddreißigstes Heft. Bauer \& Raspe, Nürnberg.

Yu D.S., van Achterberg C. \& Horstmann K. 2012. World Ichneumonoidea 2011. Taxonomy, biology, morphology and distribution. Available from http://www.taxapad.com/taxapadmain.php [accessed 25 Jun. 2016].

Manuscript received: 19 March 2017

Manuscript accepted: 16 June 2017

Published on: 14 December 2017

Topic editor: Gavin Broad

Section editor: Max Barclay

Desk editor: Kristiaan Hoedemakers

Printed versions of all papers are also deposited in the libraries of the institutes that are members of the EJT consortium: Muséum national d'Histoire naturelle, Paris, France; Botanic Garden Meise, Belgium; Royal Museum for Central Africa, Tervuren, Belgium; Natural History Museum, London, United 
Kingdom; Royal Belgian Institute of Natural Sciences, Brussels, Belgium; Natural History Museum of Denmark, Copenhagen, Denmark; Naturalis Biodiversity Center, Leiden, the Netherlands; Museo Nacional de Ciencias Naturales-CSIC, Madrid, Spain; Real Jardín Botánico de Madrid CSIC, Spain. 